\title{
A COMPARATIVE STUDY OF THE POST-OPERATIVE MATERNAL COMPLICATIONS OF ELECTIVE VERSUS EMERGENCY LOWER SEGMENT CAESAREAN SECTION- A SECONDARY DATA ANALYSIS
}

Bappaditya Som ${ }^{1}$, Narayan Bhaumik ${ }^{2}$

${ }^{1}$ Assistant Professor, Department of Obstetrics and Gynaecology, Tripura Medical College and Dr. BRAM Teaching Hospital, Hapania, Tripura West, India.

2Professor, Department of Obstetrics and Gynaecology, Tripura Medical College and Dr. BRAM Teaching Hospital, Hapania, Tripura West, India.

ABSTRACT
BACKGROUND
Caesarean delivery is defined as the birth of a foetus through incisions in the abdominal and uterine wall. Several studies conducted
across India have shown alarming increase in the rate of caesarean section deliveries. Depending on the indication, it may be elective
or emergency in nature. Caesarean sections are also associated with some maternal morbidity.
Aims and Objectives- To compare the maternal complications between elective and emergency lower segment caesarean section.

\section{MATERIALS \& METHODS}

A secondary data analysis was conducted in the Department of Obstetrics and Gynaecology, Tripura Medical College \& Dr BRAM Teaching Hospital, Hapania, West Tripura. 290 cases of elective and 259 cases of emergency LSCS with singleton pregnancy, from January 2016 to December 2016 were included in this study.

\section{RESULTS}

Majority of the participants (54.10\%) of the elective group did not suffer from complications compared to emergency group $(10.40 \%)$.

\section{CONCLUSION}

Maternal morbidity was found more in emergency caesarean sections than in elective. Though emergency operations are unavoidable, planning can help in minimising complications.

\section{KEY WORDS}

Caesarean Section, Emergency, Elective, Complication.

HOW TO CITE THIS ARTICLE: Som B, Bhaumik N. A comparative study of the post-operative maternal complications of elective versus emergency lower segment caesarean section- a secondary data analysis. J. Evolution Med. Dent. Sci. 2018;7(49):5278-5280, DOI: $10.14260 /$ jemds/2018/1171

\section{BACKGROUND}

Caesarean delivery is defined as the birth of a foetus through incisions in the abdominal wall and the uterine wall. Caesarean section is often a lifesaving procedure that is firmly encountered in obstetric practice. Today, it is one of the most commonly performed surgical procedures, but unfortunately caesarean sections are associated with some maternal morbidity.(1)The steadily increasing global rate of caesarean section have become one of the most debated topics in maternity care as its prevalence has increased alarmingly in the last few years.(2)Several studies conducted across India have shown alarming increase in the rate of caesarean section deliveries.(1)

Postpartum maternal morbidity associated with caesarean sections includes wound sepsis, postpartum haemorrhage, endometritis, chest infection, septicaemia, febrile morbidity, blood transfusion complication, abdominal distension, burst abdomen, urinary tract infection(3)and anaesthesia related

'Financial or Other Competing Interest': None.

Submission 26-10-2018, Peer Review 19-11-2018,

Acceptance 25-11-2018, Published 03-12-2018.

Corresponding Author:

Dr. Narayan Bhaumik,

Professor, Department of Obstetrics and Gynaecology,

Tripura Medical College and

Dr. BRAM Teaching Hospital,

Hapania-799014, Tripura West, India.

E-mail: nbhaumikdr@gmail.com

DOI: $10.14260 /$ jemds $/ 2018 / 1171$

\section{(c) (1) $(9)$}

complications. Depending on the indication, it can be elective or emergency in nature. Elective caesarean is when the procedure is done at a prearranged time and hence ensures better time for management. In emergency caesarean, it is done due to acute emergency.(4)The complications are usually less in case of elective caesarean as compared to emergency. ${ }^{(5)}$

\begin{abstract}
Aim of the Study
To compare the post-operative maternal complications in elective and emergency lower section caesarean section in Tripura Medical College and Dr. BRAM Teaching Hospital, Hapania.
\end{abstract}

\section{MATERIALS \& METHODS}

A secondary data analysis was conducted in the Department of Obstetrics and Gynaecology, Tripura Medical College \& Dr BRAM Teaching Hospital, Hapania, West Tripura, India. Cases of lower section caesarean sections with singleton pregnancy from January 2016 to December 2016 were included in this present study. The total number of cases of lower segment caesarean sections conducted during this period was 738 . Inclusion criteria was fixed to having detail history, full laboratory investigation, indication of operation, age between 21 and 35 years, $\mathrm{Hb} \%$ level more than $9.0 \mathrm{gm} / \mathrm{dl}$ and no other major medical disorder. Out of 738 cases only 540 cases were eligible for the present study. Out of these 540 cases, 290 cases were elective LSCS and remaining 250 cases were emergency LSCS. The outcome indicators for the study was indication of 
caesarean section, fever, wound infection, wound dehiscence, urinary tract infection, abdominal distension, anaemia, postpartum haemorrhage, prolonged catherization, prolonged hospital stay. Data was in Microsoft excel 2007 and analysed using open R software. Results expressed in frequency and percentage. Permission from Medical Superintendent of Tripura Medical College \& Dr BRAM Teaching hospital was taken.

\section{RESULTS}

\begin{tabular}{|c|c|c|}
\hline Gravida & $\begin{array}{c}\text { Elective (\%) } \\
\text { (n =290) }\end{array}$ & $\begin{array}{c}\text { Emergency (\%) } \\
\text { (n= 250) }\end{array}$ \\
\hline Primi & $180(62.07 \%)$ & $138(55.20 \%)$ \\
Multi & $110(37.93 \%)$ & $112(44.80 \%)$ \\
\hline \multicolumn{2}{|c|}{ Table 1. Distribution according to Gravida } \\
\hline
\end{tabular}

In the present, (table no. 1) elective group majority were primi gravida (62.07\%), also in emergency group majority were Primi gravida (55.20\%).

\begin{tabular}{|c|c|c|}
\hline \multicolumn{2}{|c|}{ caesarean section (27.20\%) followed by dystocia (14.40\%). } \\
\hline Intra-Operative Complication & Elective (\%) (n= 290) & $20(8.00 \%)$ \\
\hline Haemorrhage & $12(4.14 \%)$ & $13(5.20 \%)$ \\
PPH & $7(2.41 \%)$ & $8(3.20 \%)$ \\
Anaesthesia Complications & $6(2.07 \%)$ & $5(2.00 \%)$ \\
Blood Transfusion & $3(1.03 \%)$ & $2(0.80 \%)$ \\
Bladder Injury & $0(0 \%)$ & $202(80.80 \%)$ \\
No Complication & $262(90.34 \%)$ & $(\mathbf{2 5 0 )}$ \\
\hline \multicolumn{2}{|c|}{ Table 3. Comparison between Intra-Operative Maternal Complications }
\end{tabular}

The present study (Table no 3) in intra - operative complication is less in elective group compared to emergency group (OR = 0.44 , $\mathrm{p}$ value $=0.001$ ) .

\begin{tabular}{|c|c|c|}
\hline Post-Operative Complication & Elective (\%) (n= 290) & Emergency (\%) (n= 250) \\
\hline Fever & $12(4.14 \%)$ & $35(14.00 \%)$ \\
\hline Wound Infection & $7(2.41 \%)$ & $34(13.60 \%)$ \\
\hline Wound Dehiscence & $11(3.79 \%)$ & $6(2.40 \%)$ \\
\hline Urinary Tract Infection & $22(7.59 \%)$ & $21(8.40 \%)$ \\
\hline Abdominal Distension & $15(5.17 \%)$ & $29(11.60 \%)$ \\
\hline Anaemia & $20(6.90 \%)$ & $21(8.40 \%)$ \\
\hline Post-Partum Haemorrhage & $16(5.52 \%)$ & $32(12.80 \%)$ \\
\hline Prolonged Catherization & $15(5.17 \%)$ & $13(5.20 \%)$ \\
\hline Prolonged Hospital Stay & $11(3.79 \%)$ & $23(9.20 \%)$ \\
\hline Anaesthesia Complication & $7(2.41 \%)$ & $10(4.00 \%)$ \\
\hline No Complication & $154(53.10 \%)$ & $26(10.40 \%)$ \\
\hline
\end{tabular}

In the present study, (table no. 4) it was found that urinary tract infection is more common in elective group (7.59\%) and second common complication in elective group was anaemia (6.90\%). Fever is more common in emergency group (14.00\%) followed by wound infection (13.60\%).

\section{DISCUSSION}

The aim of the study was to compare the maternal postoperative complication between elective and emergency lower section caesarean section. In our study in elective cases $62.07 \%$ were primi gravida and $37.93 \%$ were multi gravida. In the emergency group $55.20 \%$ were primi gravida and $44.80 \%$ were multi gravida.

Another study done in Manassery(5) found that in elective group multi gravida $(84 \%)$ were more number than primi gravida (16\%), where in emergency group primi gravida

\begin{tabular}{|c|c|c|}
\hline Indications & $\begin{array}{c}\text { Elective (\%) } \\
\text { (n = 290) }\end{array}$ & $\begin{array}{c}\text { Emergency } \\
\text { (\%) (n= 250) }\end{array}$ \\
\hline Previous Caesarean Section & $122(42.07 \%)$ & $68(27.20 \%)$ \\
Dystocia & $11(3.79 \%)$ & $36(14.40 \%)$ \\
Mal presentation & $15(5.17 \%)$ & $19(7.60 \%)$ \\
Foetal distress & $3(1.03 \%)$ & $29(11.60 \%)$ \\
CPD & $56(19.31 \%)$ & $23(9.20 \%)$ \\
Maternal Desire & $22(7.59 \%)$ & $12(4.80 \%)$ \\
Abruption & $5(1.72 \%)$ & $5(2.00 \%)$ \\
Placenta Praevia & $9(3.10 \%)$ & $08(3.20 \%)$ \\
IUGR & $17(5.86 \%)$ & $12(4.80 \%)$ \\
PROM & $15(5.17 \%)$ & $14(5.60 \%)$ \\
Hypertensive Disorder & $8(2.76 \%)$ & $12(4.80 \%)$ \\
Bad Obstetric History & $7(2.41 \%)$ & $06(2.40 \%)$ \\
Others & -- & $06(2.40 \%)$ \\
\hline \multicolumn{3}{|c|}{ Table 2. Indications of the Lower Segment Caesarean } \\
\hline \multicolumn{2}{|c|}{ Section }
\end{tabular}

In the present study, (table no. 2) the major indications for elective caesarean sections found to be previous caesarean Section (42.07\%), followed by CPD (19.31\%). In emergency caesarean section cases the major indications were previous caesarean section (27.20\%) followed by dystocia (14.40\%). 


\section{Jemds.com}

Most common post-operative complication was found to be urinary tract infection in elective group (7.59\%) and fever $(14.00 \%)$ in emergency group. Lisha Govind $\mathrm{KV}$ et al ${ }^{(5)}$ and Diana $V$ at al.(7) also found UTI as most complication in elective group.

\section{CONCLUSION}

Maternal morbidity was found more in emergency caesarean sections than in elective. Though emergency operations are unavoidable, elective operation and planning can help in minimising complications.

\section{REFERENCES}

[1] Daniel S, Viswanathan M, Simi BN, et al. Study of maternal outcome of emergency and elective caesarean section in asemi-rural tertiary hospital. National Journal of Medical Research 2014;4(1):14-8.

[2] Lee SI, Khang YH, Lee MS. Women's attitudes toward mode of delivery in South Korea -- a society with high caesarean section rates. Birth 2004;31(2):108-16.

\section{Original Research Article}

[3] Raees M, Yasmeen S, Jabeen S, et al. Maternal morbidity associated with emergency versus elective caesarean section. J Postgrad Med Inst 2012;27(1):55-62.

[4] Elvedi-Gasparovic V, Klepac-Pulanic T, Peter B. Maternal and fetal outcome in elective versus emergency caesarean section in a developing country. Coll Anthropol 2006;30(1)113-8.

[5] Govind LKV, Rajesh TV. Obstetric outcome in elective vs emergency caesarean section. Indian Journal of Research 2018;7(3):5-6.

[6] Abha S, Reema C. A recent way of evaluating caesarean birth. J Obstet \& Gynecol India 2009;59(6):547-51.

[7] Diana V, Tipandjan A. Emergency and elective caesarean sections: comparison of maternal and fetal outcomes in a suburban tertiary care hospital in Puducherry. Int J Reprod Contracept Obstet Gynecol 2016;5(9):3060-5.

[8] Gayathry D, Guthi VR, Bele S, et al. A study of maternal morbidity associated with caesarean delivery in tertiary care hospital. Int J of Community Med Public Health 2017;4(5):1542-7. 